\title{
An Application Evaluation Determination Production Factors Toward the Cause of Oil- Losses
}

\author{
$1^{\text {st }}$ Firman $^{1}, 2^{\text {nd }}$ Rizqi Claudia Wardani ${ }^{2}$ \\ \{firman@unimudasorong.ac.id ${ }^{1}$,wanda@unimudasorong.ac.id ${ }^{2}$ \} \\ Universitas Pendidikan Muhammadiyah Sorong, West Papua, Indonesia
}

\begin{abstract}
In Petroleum field, the process of delivery crude oil that production always used pipeline together with an Agreement Utilization System Together ("Pipeline Transportation Agreement" or "Handling and Transportation Agreement"). The cause of delivery system using same pipeline, it created some problems those are oil losses between Production Station as delivery point with the Center Production Collector (PPP) as sales point. This problem caused problem in petroleum transportation system using pipe system because it always created some claims that the volume of crude oil which received is subside from the crude oil which delivery. Because of the reason it needs a study evaluation oil losses in identifying the cause of losses, it determine how large the volume losses and decide the factors of production correction to each crude oil from each fields. To handle the problem, it needs a web basis application which may evaluate and determine the factors Production Correction the cause of oil-losses which found from the factors of oil shrink. The factor of oil emulsion and factor of oil evaporation. This application will be created using programming language PHP. MySQL is a technology which used for database from this application, the methodology that used in this study is Waterfall Method that included manipulation system stages, need analysis, designing, implementation, and tests stages. The entity of this application are admin and user. This application optimizing the previous evaluation method which still conducting in manual way. The data is displayed more accurate (less of human-error), efficient, and able to update in real time because it saved inside the database. The result of analysis and evaluation this application can be a reference in comparing oil losses that happened in the field with the result of mathematic calculation, it will become proved by the Center of Production Collector (PPP) or claim that usually happened.
\end{abstract}

Keywords : Oil Losses, Correction Production Factor, Mixing Oil, Oil Emulsion, Oil Evaporation.

\section{Introduction}

In this life almost all will be connected with pipe and system. In every multi-storey building for offices, hospital, hotel, and companies. Most of them used pipe, for sanitation, to have air conditioner, even for irrigated the fluid to storage tank. Those pipes is very necessary as tools to irrigate fluids that will be process. Fluid is something that cannot be separate from our daily life even in liquid or gas.

In Petroleum field, the process of delivery crude oil, the production always used pipeline together with an Agreement Utilization System Together ("Pipeline Transportation Agreement" 
or Handling and Transportation Agreement"). The cause of delivery system using same drain pipe. It created some problems; those are oil losses between Production Station as delivery point with the Center Production Collector (PPP) as Sales Point. This problem caused problem in crude oil transportation system using pipe system because it always created some claims that the volume of crude oil which received is subside from the crude oil which is delivery. As the reason it need more identification to the oil losses and to determine how much volume losses and decide the correction production factors to each crude oil which delivery to the producer in SP (Station Point) which is based on the nature of petroleum from every fields that caused shrinkage, evaporate, and emulsion of the petroleum.

To evaluate the oil losses that happened, there will be a lot of data should be written and calculate to determine the correction production factors in every crude oil that existed in the field. And according to the calculation data, it will produce some study about the cause factors of oil losses and the total or how much volume losses in every SP (station point). In this whole time the calculation is conducted in manual way, such as in calculating oil density when blending process, specific gravity test, distillation calculation, water content and sediment analysis (BS \& W). In calculating the correction factors and determine how much the volume losses which happened. Since there are many calculations needed, sometimes it takes much time and the calculation may be not accurate because some human error factors during the calculation.

To solve the problem, it need an application that can help to manage the data. The data which connected to the oil losses activity inside oil pipeline. So, it formulated some problem based on the problem background. The research question will be how to create an Application web basis to evaluate and analyze the oil losses that happened in the stream of oil pipe, the limitation of this research; a) The data used to create the application is secondary data or the data that according from the research result in evaluation process of correction production factor the cause of oil losses in stream of oil pipe. b) In this application used some tests method to determine three factors that always happened such as shrinkage, evaporation, and emulsion of crude oil. c) This application consist of two main entities; admin and user. Admin is only able to manage the user data that is add, delete, and change. While the user is able to manage whole data production. This research is aimed to create an application web basis to evaluate and analyze the correction production factors which caused oil losses inside oil the pipeline

\section{Literature Review}

\subsection{Application}

Application is a system that designed and arranged to create some information which integrated using computer facility as its support. Application itself is English, the meaning is to apply, to purpose, to use. While the definition of application is a program that ready to use to do a function for the application user and to use another application which able to use by a facility that to be purpose. Application as a program that ready to use by human in doing wok using computer (Fajarianto,et all, 2014).

\subsection{DBMS (Database Management system)}

DBMS (Database Management system) is a software that designed to help in maintain and to use data collection with large size and the total of stuffs system will be depend on to the use (Ramakrishnan dan Gehrke, 2003). Physic basis data management did not conduct by the user 
directly, but it will be handle by special a software (system). This software called DBMS will be determine how the data will be organized, in using the data together, accuracy force data, and etc (Fathansyah,2012).

\subsection{Website}

Website atau World Wide Web (WWW) is an information space that used by global identifier that called URL (Uniform Resource Indentifier) to identify benefit source, so through this web, user can find some information in many kinds. The information that created by web could be in text, picture, audio visual, model, film graphic, and the others. In the beginning web browser software text basis, but now days it developed with face to face graphic, so the user can do some browsing easily, for example the popular web browser is internet explorer, Mozilla FireFox, Opera, Google Chrome, Netscape, Navigator dan lain-lain (Nurhayani, 2013).

\subsection{Waterfall Method}

Waterfall method in model did some approach in systematic and arranged structural started from the manipulate system to the analysis stage or designing, (coding) program written, testing or verification, and maintenance (Pascapraharastyan, et all, 2014). This method called Waterfall because in this stage, step by step should be done and wait until the previous step finished and will running sequentially (Pressman, 2008). In general the stages in waterfall model is appeared in the picture bellow.

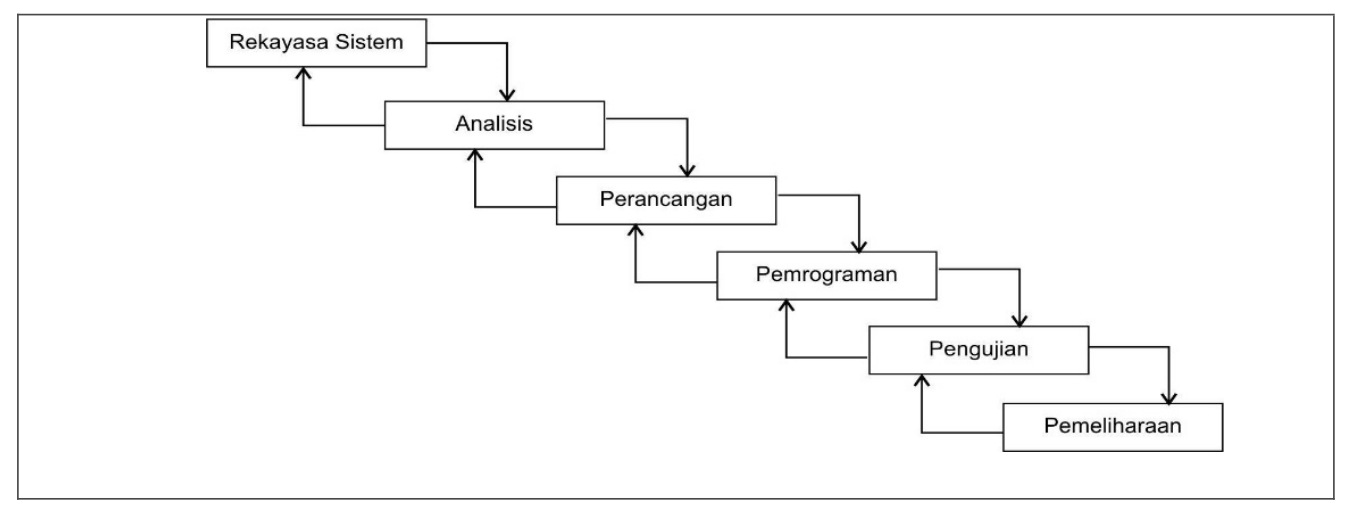

Fig. 1 Waterfall Model

\subsection{Application Development Device}

\subsubsection{Page Hypertext Preprocessor (PHP) Language Program}

PHP Is Page Hypertext Preprocessor that use as script server-side language in developing web that inserted in HTML document (Warman dan Zahni, 2013).

PHP is program web basis that has ability to process and to manage data in dynamic. PHP can be said as server-side embedded script language, scripting language merged with HTML and it is running to server-side. It means the program instruction that user written will be fully conducted by the server but it can be inserted in usual HTML page meanwhile the one already sent to the browser only the result (Nurhayani, 2013; Sugiantoro,2005). 


\subsubsection{MySQL}

My Structured Query Language or MySQL is a program maker and manage the database or it usually called Database Management System or DBMS (Sugiantoro,2005). MySQL is one of derivative main concept to select and insert data. The advantage of database system (DBMS) is known by the way of optimizer in doing command process SQL, that created by user and application programs (Nurhayani, 2013). Usual HTML page meanwhile the one which sent to the browser is only the result (Nurhayani, 2013; Sugiantoro, 2005).

\subsection{Correction Production Factor}

In transportation petroleum system used pipe net usually has claimed that the crude oil which received has less volume than the crude oil that delivery. In fact, in point receive and delivery, the quantity of oil like SG and BS\& W become the basis of oil volume calculation that has been checked and agreed by both side, for example, to present witness from the receiver side during oil measurement. From the observation of crude oil system production which connected to custody transfer, oil-losses may happened because of these factors:

a) The limit of tanks total in the production fields become delivery-receive point will be limited to the duration of stay (Settling time). To separate the water and sediment, and the important one if emulsion happened stable.

b) There will be emulsion of crude oil-water that has stable high level so the separator of water from crude oil is difficult to do in a short time.

c) There is production field that did not use demulsifier and warming treatment in breaking the emulsion.

d) The tank conditions during delivery-receive that possible to lose crude oil because mild fraction evaporation of crude oil.

e) There will be no tools to measure the quantity of flow meter, so the crude oil volume determined by the level of liquid inside the tank. This thing will improve the possibility of mistake because it included more its variable, for example the tank condition that in times there will be waste left in the base, and there will be more laboratory tests that needed, to decide the point in collecting sample which will be analyze and the analysis will be the determination of crude oil volume.

f) The mistake during conducting the procedure in did measurement of crude oil volume, in collecting sample that will be analyze and laboratory analysis to determine the crude oil volume.

g) There will be shrinkage of crude oil because of two or more kinds of crude oil that mixed in pipe or in the same tank. According to the cause of oil-losses that mentioned above and it is believed that the crude oil flow in steady state, the scale of petroleum volume is shown in picture below:

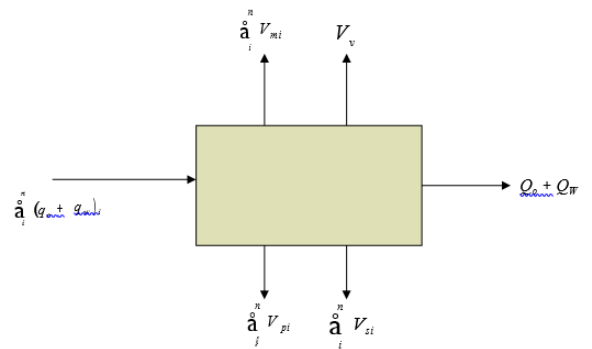

Fig 2. the scale of crude oil volume in custody transfer 


\section{Method}

In this chapter will be discussed three stages of waterfall method that used to create systems that is manipulation stage and modelling system, system analysis needed, and design. In stage of analysis needed, the software will be design in Data Flow Diagram (DFD) and in designing basis data that included designing Entity Relationship Diagram (ERD) and will be discuss also about user interface.

\subsection{Requirements Gathering}

\subsubsection{System Analysis in Progress}

System analysis is a picture about system that still in progress in the reality of petroleum field. Every station production (SP) that delivery the oil through pipe to the center production collector point always has disadvantages that is oil-losses. To solve the claim of oil-loss from each station should conduct some evaluation to the correction production of oil-loss factor. Until now the calculation and determination of correction production factors still use manual way that was not efficient and the result still not accurate. The analysis system aimed to make new system that able to computerized, so it will more effective and efficient. With this application web basis, every station will be very easy to do evaluation to the correction production oil-loss factors so the claims will be not happen.

\subsubsection{Needs Analysis}

This analysis system is aimed to create that new system that should be computerized so it will more effective and efficient. Through this application web basis, every station will be very easy to do evaluation to the correction production oil-loss factors so the claims will never happen.

\subsubsection{Functional Needs}

1. User

This application can be used in functional such as:
a. Data station management.
b. Oil data management.
c. Do simulation of shrinkage, emulsion and evaporation of oil.
d. Observe the result from the correction production factor evaluation

2. Admin
a. Do validation or checking production data from the result of user input.
b. Observe the result from the correction production factor evaluation
c. Manage the user data.

\subsubsection{Non-Functional Needs}

Non-functional needs from the system that has been created such as:

1. User Interface (UI) or interface that interested and easy to use.

2. User Interface (UI) or interface that dynamic as responsive web.

\subsection{System Design}

The steps of designing is a step of identify the functional needs in preparing the system design build implementation which aimed to plan and design the system to fulfill the user needs system and to understand the stages of information and process in system.

In designing system consisted of make Data Flow Diagram (DFD), Designing basis data 
(ERD, designing table and RAT), Designing menu structural and designing interface. The stages will be conducted in system design.
a. Process Design
b. Database Design
c. Menu Structure Design
d. User Interface Design

\subsubsection{Process Designing}

In this stage of process designing is very necessary in creating information system. In the purpose to describe how the system created. In designing process, it used Data Flow Diagram (DFD) from DFD level 0 until DFD level 2.

\section{Result}

\subsection{Hardware that used}

The analysis of hardware is aimed to know in accurate the kind of hardware needed. And the hardware that used in this application to develop the application progress can be see below in table 1

Table 1. Hardware that used table

\begin{tabular}{|l|l|l|}
\hline No & \multicolumn{1}{|c|}{ Kind of Hardware } & \multicolumn{1}{|c|}{ Note } \\
\hline 1. & Computer/Laptop & ASUS, Toshiba \\
\hline 2. & Processor & Intel(R) Core \\
\hline 3. & RAM & $2.1 \mathrm{GHz}$ CPU M 350 @ 2.13GHz (4 CPUs), \\
\hline 4. & Hard disk & $2048 \mathrm{Mb}$ \\
\hline 5. & VGA Graphic & $500 \mathrm{~Gb}$ \\
\hline 6. & Mouse and Keyboard & Intel HD Graphic300 \\
\hline
\end{tabular}

\subsection{Software that is used}

The need of software is a system that necessary to do processing system. The function is to support the application. Software that is used to develop and to be implementation in this application will be seen below in table 2

Tabel 2. The Software that is used Table

\begin{tabular}{|l|l|l|}
\hline No & Kind of Software & Name of software \\
\hline 1. & Operation system & Windows 7 and Windows 8Pro 64-bit \\
\hline 2. & Editor Programming & Net Beans IDE 8.0 \\
\hline 3. & $\begin{array}{l}\text { Software web } \\
\text { server }\end{array}$ & $\begin{array}{l}\text { WAMPSERVER 2.4 64-bit } \\
\text { Apache 2.4.4 } \\
\text { Web Server } \\
\end{array}$ \\
Database Server & $\begin{array}{l}\text { MySQL 5.5.32 } \\
\text { PHP 5.4.22 }\end{array}$ \\
\hline 4. & Programming Language & PHP, HTML,CSS,Java Script \\
\hline 5. & Web Browser & Mozilla Firefox dan Google Chrome \\
\hline 6. & Picture Editor & Paint, Corel Draw X6 \\
\hline
\end{tabular}




\subsubsection{Admin Page Implementation}

Admin page implementation is special running by the admin that is facility to manage the data that included in the system. The data which have been input by the user will get accurate data validation by the admin first.

a. Home Page

Home page is web page that will be used by the admin has menu that is home page. Production data, correction factor, graphic plot, conversion and data user. The appearance home page can be seen in Fig 3 .

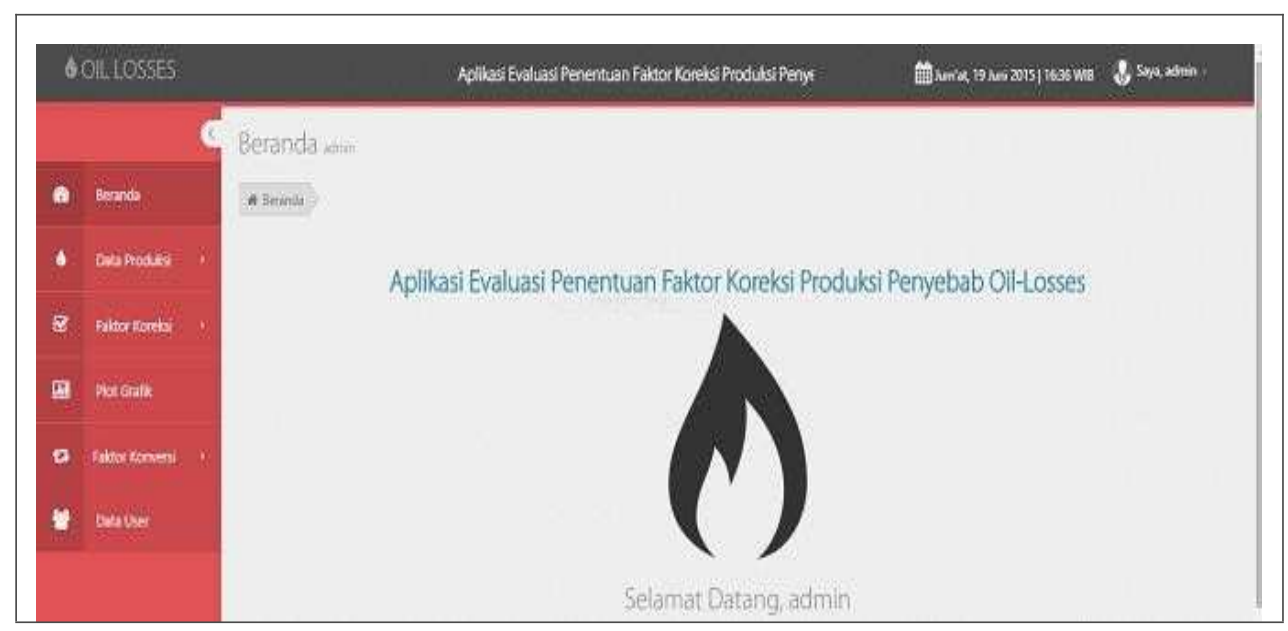

Fig 3. Home Page Appearance

b. Center Page of Production Collector

This page will display the data of Production Collector Center (PPP) that has been input by the user. Admin able to see whole PPP data from all groups and segments. Admin also can see the detail of PPP and delete the data, the display of Production Collector Center page can be seen in Fig 4.

\begin{tabular}{|c|c|c|c|c|c|c|c|c|}
\hline \multicolumn{5}{|c|}{ Aplikasi Evaluasi Penentuan Faktor Koreksi Produksi Penyebab OïLosses } & \multicolumn{4}{|c|}{ 电Jum'at, 19 Juni 2015 | 16:59 WBB \& Saya, admin } \\
\hline \multicolumn{9}{|c|}{ Pusat Pengumpul Produksi admin } \\
\hline * & \multicolumn{8}{|c|}{ Pusat Pengumpul Produksi } \\
\hline \multicolumn{8}{|c|}{ Data Pusat Pengumpul Produksi } & $v$ \\
\hline$\rightarrow$ No & 놓 Nama PPP & - Volume Pompa (barel) & d Volume Terima (barel) & $\triangle$ Densitas Total & Y Spesifik Gravitasi Total & \multicolumn{3}{|c|}{ FAlsi } \\
\hline 1 & LIMAU GROUP & 16973 & 16531 & 0.8871 & 0.8879 & Q Uhat & BHaps & \\
\hline 2 & PGD-TITIS & 1133 & 1064 & 0.7343 & 0.7351 & Quthe & Q Hapus & \\
\hline 3 & OGAN GROUP & 1649 & 1637. & 0.8991 & 0.89985 & Quatit & gitapus & \\
\hline
\end{tabular}

Fig 4. Production Collector Center Page Display 


\subsubsection{Alpha Test}

Alpha test is conducted in developer side the aim is to identify the problem (error) before finally sent to the user. Alpha Test should be conducted in the area that under control (Pressman, 2002). The examiner of alpha test is information technique students' UPN "Veteran" Yogyakarta. The name of students is shown in the table 3

Table 3. The names of Alpha Test Examiner Table

\begin{tabular}{|l|l|l|}
\hline No & \multicolumn{1}{|c|}{ Name } & \multicolumn{1}{|c|}{ Job } \\
\hline 1 & Abdul Haris Muhammad S.T. & Alumni Teknik Informatika UPN 'Veteran’ Yogyakarta \\
\hline 2 & Anggit Ferdita Nugraha S.T. & Alumni Teknik Informatika UPN'Veteran’ Yogyakarta \\
\hline 3 & Angkoso Brami Prasojo S.T. & Alumni Teknik Informatika UPN 'Veteran' Yogyakarta \\
\hline 4 & Anindya Putri Larasati & Alumni Teknik Informatika UPN 'Veteran' Yogyakarta \\
\hline 5 & Asydhiqi Satrio Kusuma & Alumni Teknik Informatika UPN 'Veteran' Yogyakarta \\
\hline 6 & Indra Aprillinfanteri Army S.T. & Alumni Teknik Informatika UPN 'Veteran' Yogyakarta \\
\hline 7 & Liestia Kharina Novianty S.T. & Alumni Teknik Informatika UPN 'Veteran' Yogyakarta \\
\hline 8 & M. Bagus Prasetyo & Alumni Teknik Informatika UPN 'Veteran' Yogyakarta \\
\hline 9 & Mia Adriana & Alumni Teknik Informatika UPN 'Veteran' Yogyakarta \\
\hline 10 & Monig Dewi Yuskariri S.T. & Alumni Teknik Informatika UPN 'Veteran' Yogyakarta \\
\hline
\end{tabular}

The result of alpha test can be seen in the table below:

Table 4. Result of Validation test of Alpha Test Table

\begin{tabular}{|c|c|c|c|c|c|c|}
\hline \multirow{2}{*}{ No } & \multirow{2}{*}{ Test } & \multicolumn{5}{|c|}{ Score } \\
\hline & & 1 & 2 & 3 & 4 & 5 \\
\hline \multicolumn{7}{|c|}{ Admin Page : } \\
\hline 1 & Does the page working well? & & & & 3 & 7 \\
\hline 2 & Does the production data page working well? & & & & 6 & 4 \\
\hline 3 & Does the Production Station page working well & & & & 5 & 5 \\
\hline 4 & Does the page by data user working well? & & & & 4 & 6 \\
\hline 5 & Does the add data user page working well? & & & 1 & 6 & 3 \\
\hline 6 & $\begin{array}{l}\text { Does the function of calculation simulation of mixing oil } \\
\text { working well? }\end{array}$ & & & 3 & 5 & 2 \\
\hline 7 & $\begin{array}{l}\text { Does the calculation simulation of oil emulsion working } \\
\text { well? }\end{array}$ & & & & 7 & 3 \\
\hline 8 & $\begin{array}{l}\text { Does the function of calculation of oil evaporation } \\
\text { working well? }\end{array}$ & & & 2 & 8 & \\
\hline 9 & Does the observation point working well? & & & 2 & 8 & \\
\hline 10 & Does the User Inter face interesting? & & & & 7 & 3 \\
\hline \multicolumn{7}{|c|}{ User Page: } \\
\hline 11 & Does the Home Page working well? & & & & 3 & 7 \\
\hline 12 & $\begin{array}{l}\text { Does the function of management data by the Production } \\
\text { Collector Center working well? }\end{array}$ & & & & 8 & 2 \\
\hline 13 & $\begin{array}{l}\text { Does the function of production station data management } \\
\text { working well? }\end{array}$ & & & 1 & 7 & 2 \\
\hline 14 & Does the function management of oil data working well? & & & 2 & 7 & 1 \\
\hline 15 & $\begin{array}{l}\text { Does the function of simulation calculation oil emulsion } \\
\text { working well? }\end{array}$ & & 2 & 2 & 5 & 1 \\
\hline 16 & $\begin{array}{l}\text { Does the function of simulation calculation oil emulsion } \\
\text { working well? }\end{array}$ & & & & 5 & 5 \\
\hline
\end{tabular}




\begin{tabular}{|c|c|c|c|c|c|c|}
\hline \multirow{2}{*}{ No } & \multirow{2}{*}{ Test } & \multicolumn{5}{|c|}{ Score } \\
\hline & & 1 & 2 & 3 & 4 & 5 \\
\hline 17 & $\begin{array}{l}\text { Does the function of simulation calculation of oil } \\
\text { evaporation working well? }\end{array}$ & & & & 4 & 6 \\
\hline 18 & $\begin{array}{l}\text { Does the calculation of correction factor in oil shrinkage } \\
\text { working well? } t\end{array}$ & & & 3 & 5 & 2 \\
\hline 19 & $\begin{array}{l}\text { Does the calculation of correction emulsion oil giving an } \\
\text { accurate result and working well? }\end{array}$ & & & & 7 & 3 \\
\hline 20 & $\begin{array}{l}\text { Does the calculation of correction oil evaporation factor } \\
\text { giving an accurate result and working well? }\end{array}$ & & & 2 & 8 & \\
\hline 21 & $\begin{array}{l}\text { Does the function of total loss calculation giving an accurate } \\
\text { result and working well? }\end{array}$ & & & 2 & 8 & \\
\hline 22 & $\begin{array}{l}\text { Does the calculation of sharing loss oil giving an accurate } \\
\text { result and working well? }\end{array}$ & & & & 7 & 3 \\
\hline 23 & $\begin{array}{l}\text { Does the graphic production page giving an accurate } \\
\text { result and working well? }\end{array}$ & & & & 3 & 7 \\
\hline 24 & $\begin{array}{l}\text { Does the graphic of oil total loss giving an accurate result } \\
\text { and working well? }\end{array}$ & & & & 6 & 4 \\
\hline 25 & $\begin{array}{l}\text { Does the calculation function of pressure conversion } \\
\text { giving an accurate result and working well? }\end{array}$ & & & & 5 & 5 \\
\hline 26 & $\begin{array}{l}\text { Does the function of volume conversion giving an } \\
\text { accurate result and working well? }\end{array}$ & & & 3 & 5 & 2 \\
\hline 27 & $\begin{array}{l}\text { Does the function of change password page working } \\
\text { well? }\end{array}$ & & & & 7 & 3 \\
\hline 28 & Does the function of list of terms working well? & & & 2 & 8 & \\
\hline 29 & Does the function of help page working well? & & & 2 & 8 & \\
\hline 30 & Does User Interface interesting? & & & & 7 & 3 \\
\hline & Jumlah & & 2 & 27 & 182 & 89 \\
\hline
\end{tabular}

The result of the test use test validation tests and it concluded that the respondent choose very good (5) at least 89 answers, good (4) for 182 answers, enough (3) for 27 answers, poor (2) for 2 answers and very poor (1) for 0 answer. To know the percentage from every choice can use the formulation below:

$$
\text { Percentage }=\frac{\text { Score }}{\text { Total Question } \times \text { Total Respondent }} \times 100 \%
$$

The percentage result of assessment the ones who give very good, good, enough, poor and very poor answer. The result for Very good is $29.66 \%$, Good is $60.67 \%$, Enough is $9 \%$, Poor is $0,67 \%$, and Very poor is $0 \%$.

According to the assessment system, the result of validation test of alpha test is more that $50 \%$. the respondents who give good answer so it can conclude that the application that has been create that fulfilled the needs of the last user and it can be apply in the real location.

\section{Conclusion and Suggestion}

In this chapter will be explain about the conclusion and suggestion from the result analysis, implementation, and test in previous chapters that already followed by the system development. 


\subsection{Conclusion}

According to analysis result, designing, and implementation that already done, so it can concluded that:

1. It has been produced an application web basis and it able to use by producer in every production station in the fields to evaluate and to determine the correction production factor the cause of oil losses during the distribution petroleum through pipeline.

2. The result analysis and evaluation of this application can be a reference in comparing oil losses that happened in the field with the mathematic calculation result so it become proved by the Production Collector Center (PPP) to the claims that usually happened..

3. This application optimized the evaluation to the previous manual method. The data served more accurate (less of human-error), efficient and able to update in real time because it saved inside database.

\subsection{Suggestion}

From this research that has been conducted. There are many problem solved but the development of this system is not perfect yet that is why suggestion is needed that may able to apply to develop the system continuously such as:

1. System will be effective if in the moment of determination the production correction factor because of shrinkage, the steps of process oil mixing described clearly wherever the mixing process happened. This can be implemented in dynamic from data input until the process of calculation so the mixing oil process will be dynamic and looked like exactly same with the reality that happened in the field.

2. In the same study case, the application can be develop using operating system (OS) which basis Mobile such as Android, Windows Phone, Blackberry OS and IOS.

\section{References}

[1] Andi, 2004, Aplikasi Program PHP dan MySQL untuk Membuat Web Site Interaktif, Andi : Yogyakarta.

[2] Fathansyah, 2012, Basis Data Informatika, Bandung.

[3] Kristanto, Dedy, 2012, Hand Out Inhouse Oil Losses (DK-HYD) "Oil Losses : Teory and Application".

[4] LEMIGAS, 2011, Reevaluasi Faktor Koreksi Oil Losses Field Pertamina Ep Region Sumatera - Segmen 1.

[5] Pressman Roger S, 2002, Rekayasa Perangkat Lunak Pendekatan Praktisi (Buku Satu), Andi: Yogyakarta.

[6] Ramakrishnan, Raghu dan Johannes Gehrke, 2003, Database Management System. 3rd Edition, McGraw-Hill, USA.

[7] Sidik, Betha, 2007, Pemrograman Web dengan HTML. Informatika, Bandung.

[8] Sunarfrihantono, B, 2003, PHP dan MySQL untuk Web, Yogyakarta: Andi Publisher.

[9] http://www.w3schools.com/jquery/ (diakses pada 24 Mei 2015)

[10] http://www.bp.com/en/global/corporate/about-bp/energy-economics/statistical-review-ofworld-energy/using-the- review/conversion-calculator.html (diakses pada 24 Mei 2015)

[11] http://www.highcharts.com/demo/3d-pie (diakses pada 02 Juni 2015)

[12] http://jsfiddle.net/(diakses pada 02 Juni 2015)

[13] http://diglib.lemigas.esdm.go.id/opac.php?modul=opac\&act=view_kamus (diakses pada 15 Juni 2015) 